\title{
Giving and sharing in the computer-mediated economy
}

\author{
JOHN HARVEY ${ }^{1 *}$, ANDREW SMITH ${ }^{2}$ and DAVID GOLIGHTLY ${ }^{3}$ \\ ${ }^{1}$ Horizon Digital Economy Research, University of Nottingham, Jubilee Campus, Nottingham, NG7 2TU, UK \\ ${ }^{2}$ Business School, Jubilee Campus, Nottingham University, Nottingham, NG7 2TU, UK \\ ${ }^{3}$ Human Factors Research Group, University of Nottingham, Nottingham, UK
}

\section{ABSTRACT}

The paper examines how digital technology mediates the behaviour of consumers in three online systems that facilitate offline gift giving and sharing (Freecycle, Couchsurfing, and Landshare). Findings derived from a netnography and depth interviews reveal how technology is used to enact and influence the management of identity, partner selection, ritual normalisation, and negotiation of property rights. The findings have significant implications for the design and management of systems that encourage non-monetary forms of collaborative consumption. Copyright (c) 2014 John Wiley \& Sons, Ltd.

\section{INTRODUCTION}

A variety of informal offline exchange systems have been facilitated by the internet. Consumers with common interests come together online before meeting offline for the purpose of exchanging, giving or sharing goods. Many of the services are designed and positioned as being explicitly pro-social, i.e. the participants who offer their possessions to others do so at a personal cost and without immediate gain (Penner et al., 2005). As mobile technology has become ubiquitous, the number of these systems appears to be increasing in number as a result of the improved potential to match people across space and time. Recently, there has been a surge of commercial activity in the field of 'collaborative consumption' - a term first coined by Felson and Spaeth (1978) and popularised in Botsman and Rogers, 2011 by Botsman and Rogers. These systems help consumers to exploit a spare pool of resources; they can reduce the cost of acquisition and the environmental impact of consumption in comparison to the more typical product lifecycle. Crucially, many of these systems eschew or even prohibit monetary-based transactions, favouring deliberate redistribution of resources without formalised quid-pro-quo exchange (Albinnson and Perera, 2012). Unlike comparable transactions (that rely on money to create equivalence through a shared understanding of quantified value), technology helps to mediate the transfer, aiding both donor and recipient alike. Despite the wealth of research into gift giving and sharing as well as the abundance of computer-mediated pro-social exchange systems, the role that technology plays in these economic transfers has received little attention in the consumer research literature. Dobscha and Arsel (2011) have described the emergence of these systems as a form of hybridised exchange that does not correspond to a singular prototypical behaviour such as giving, sharing, or commodity exchange (refer to Belk, 2010) but instead demonstrate characteristics of each. The core

*Correspondence to: John Harvey, Horizon Digital Economy Research Hub, University of Nottingham, Nottingham, UK.

E-mail: psxjh2@nottingham.ac.uk research objective is to understand how technology mediates the ambiguities that arise from this hybridization in order to create and perpetuate structured, ritualised behaviour. The following section reviews the principal dimensions of giving and sharing. The research design is then discussed, prior to an exposition of the results of the netnographies and depth interviews.

\section{FUNDAMENTAL CONCEPTS OF GIVING AND SHARING}

The phenomenon of gift giving has received an enormous amount of cross-disciplinary attention over the past century. Because seminal work by Mauss (1925) and Malinowski (1922) scholars in anthropology, sociology, economics, philosophy, and consumer research have examined the antecedents of giving. Sharing in contrast has received less explicit attention than gift giving but has been the focus of studies in numerous different disciplines (e.g. Benkler, 2004; Widlock, 2004; Belk, 2010). Despite this wealth of research, the scope of gift giving and sharing is so diverse and complex that application of universal rules or typologies is difficult, if not impossible. However, there are a number of dimensions that can be used to classify these types of economic exchanges, including agency, structure, ritual and property. These are now discussed in turn.

\section{AGENCY AND STRUCTURE}

Yan (2005) suggests that a core classification variable of gift giving behaviour is the agency of social actors, that is, do people exchange gifts on behalf of the respective groups that they belong to, such as family, lineage or community? Or, alternatively, is the gift exchanged between two autonomous individuals? Much of the anthropological research into gift giving examines intercommunity gifting and describes how giving as a means of economic distribution within archaic societies creates social bonds that form important macro- 
level structures. Contemporary research into gifting has primarily focused on dyadic perspectives because giving as a means of economic distribution has largely been replaced with immediate reciprocity, that is, secularised market economies. Within the field of consumer research Sherry (1983) developed a processual model of giving that provided a conceptual springboard for others in the field. Here, the gift is viewed as a continuous act of reciprocity, whereby the act of giving provides a dialectical chain between dyads. The process can be studied across three phases through which the relationship between giver and receiver progresses: gestation, prestation, and reformulation. Much of the research in this area emphasises the importance of giving and receiving as a means of fostering and maintaining interpersonal connections with family and friends (Wooten, 2000; Joy, 2001; Wooten and Wood, 2004; Bradford, 2009).

Recently, attention has been paid to the concept of intracommunity gifting, that is, non-reciprocal or asymmetric relationships of economic transfer between an individual and a community. These types of gifts are perhaps best described as a form of sharing. According to Weinberger and Wallendorf (2011), previous research has primarily focused on gifting in which the central goal is interpersonal relationship maintenance. Intracommunity gifting occurs when community members in one social position give to community members in another position in which the central goal is intracommunity, rather than interpersonal. Most of the research into giving online has been explored in relation to crowd sourcing projects and peer-to-peer networks, where gifts manifest virtually. In his study of Napster, Giesler $(2003$, 2006) acknowledges that the traditional models of dyadic gift giving offer only a limited insight into the digital sphere as a result of the one-to-many forms of giving made possible by networked technologies such as the internet. In the cases studied here, the principal form of interaction is often polyadic rather than simply dyadic: There is a degree of agential freedom on behalf of the donor that does not restrict their actions to rigid dyadic reciprocity.

\section{PROPERTY}

A gift always involves a transference or exchange of property rights. Sharing may not rely on a change of ownership like gift giving, but it always involves dual access to a property right of some sort, and this can affect how a resource is appropriated. When considering property, there are a number of characteristics that are useful to examine. Rather than analysing the simple dualism of 'public' versus 'private' property, it is useful to acknowledge that some resources can only be consumed a finite number of times and some resources can be appropriated by an individual and then excluded from others. These attributes are recognised in the political-economy literature as excludability and subtractability (Hess and Ostrom, 2003). Excludability relates to the power a person can assert over a resource in relation to other people, that is, can a person prevent another from consuming a resource? Subtractability defines the potential of a resource to be consumed repeatedly, that is, if one person consumes a resource, is it then possible to be consumed again, either by the original consumer or another? Because of the ease of replicating digital information, consumption by one person does not necessarily diminish the consumption quality for another-it is therefore not beleaguered by subtractability like most physical resources. A property right is an enforceable authority to undertake particular actions in a specific domain (Commons, 1968). "Property rights define actions that individuals can take in relation to other individuals regarding some 'thing'. If one individual has a right, someone else has a commensurate duty to observe that right" (Ostrom, 2003, p.249). Research into sharing and giving often focuses on alienability as the predominant means of understanding consumer behaviour, or as Barthes (1972, p.73) once criticised the bourgeoisie, property is seen as nothing "but a dialectical moment in the general enslavement of Nature." It makes little sense to speak of alienability (or inalienability) as a simple dualism; property rights are much more nuanced than simple changes of ownership. Many actors (either individual or grouped) can simultaneously lay claim to aspects of a resource. This has been called 'tenure niche' and can be construed in different ways depending on the type of resource being appropriated (Bruce, 1995). Ostrom and Hess (2007), updating Ostrom and Schlager, 1996) recognise a hierarchy of seven positions that can be associated with bundles of property rights: access, contribution, extraction, removal, management, exclusion, and alienation. The most basic right 'Access' is defined as the right to enter a defined physical area and enjoy nonsubtractive benefits. The highest property right that a person can attain over a resource is that of alienation, that is, the right to sell, lease or give away extraction, management, and exclusion rights. Crucially, the right of alienation is socially constituted, that is, the right of the individual always depends on the recognition and acquiescence of other people. Note that the use of the word 'alienation' here departs from other definitions of alienability within the sociological tradition to strictly focus on an absolute and transferable property right.

\section{RITUAL}

A number of anthropologists have argued that gifts and commodities co-exist in certain circumstances (Appadurai, 1986; Parry and Bloch, 1989; Carrier, 1991; Godelier, 1999). Money for instance has often been described as occupying a dual role of gift and commodity (Strathern, 1979; Gregory, 1980). Similarly, many others have described commodities becoming gifts through the transformative process of appropriation. An illustrative example of ritualised appropriation is gift wrapping that serves as transformative function, turning impersonal commodities into personalised gifts (Carrier, 1995). Rituals provide a social mechanism for the reappropriation of resources through a stereotyped sequence of activities. Belk (2010) has suggested that consumption and exchange behaviour can be delineated into three categories: commodity 
exchange, gift giving, and sharing. He suggests that the delineation between each category is often blurred, and as such, they should be defined in prototypical form rather than by rigid Aristotelian definition, that is, categories are fuzzy sets and their characteristics overlap and conflate. In the context of non-monetary based acts of exchange, as in digitally mediated gift systems, this delineation is not immediately obvious. Particularly, when non-monetary exchange online can occur in entirely digital form, for example as file sharing, or alternatively as a forum to facilitate offline giving or sharing. Previous research has suggested that ambiguity often plays a part in creating the 'liminal' (Turner, 1969) moments necessary to mediate economic transfers where the ownership of property is in a state of transition. Turner's concept of liminality was inspired by Arnold van Gennep (1960), but the notion of a 'liminoid' state was an adaptation of the concept so that the ritual moment could be seen to be ever more optional in less bounded and more secularised societies (Abrahams, 1969). Thus far, little attention has been paid to how consumers use technology to negotiate the liminoid moments that arise during non-monetary transactions such as gift giving and sharing. Dobscha and Arsel (2011) argue that hybridised exchange systems give rise to a variety of tensions as a result of the systems being marketed as simply 'giving' or 'sharing' while at the same time giving counter indications of both (as described by Belk, 2010). They suggest for instance that a system may encourage people to request and offer goods for free but discourage people to provide personal information (a counter indication of sharing) or expect reciprocity (a counter indication of gifting). These tensions suggest an ambiguous state of the resources involved, so examining the rituals involved during transference or exchange could help to shed light on how ambiguity is resolved socially.

\section{RESEARCH DESIGN}

The purpose and orientation of pro-social exchange systems varies enormously. In the research reported here, three online systems were studied (Freecycle, Couchsurfing, and Landshare), each encouraging different consumption patterns and human-computer interaction. Each of the systems were selected on the basis that they all reject the use of money and furthermore are individually unique in the way they encourage a particular form economic behaviour, that is, Freecycle encourages giving of physical tangible goods, Couchsurfing encourages giving of space, and Landshare encourages sharing of physical resources. Freecycle describes itself as being on a mission 'to build a worldwide gifting movement that reduces waste, saves precious resources and eases the burden on our landfills while enabling our members to benefit from the strength of a larger community' (2013). Members typically advertise things they no longer need, and recipients collect the item for free. It is an interesting case study as it demonstrates a form of gift giving that has received less attention than most others: disposal. Parsons and Maclaran (2009) note that much of the research in this area has tended to focus on how consumers acquire goods, rather than how they dispose of them. Consequently, gifting as disposition remains a neglected and under-theorised area in consumer research. Couchsurfing (2013) is a volunteerbased worldwide network connecting travellers with members of local communities, who offer free accommodation and/or advice. Couch surfers advertise available space for travellers to use and exchange private messages before meeting offline. The gift in this case comes generally in the form of an experience of cohabited space. Clarke (2006) notes that gift giving theory has evolved around the giving and receiving of physical goods yet experiences as gifts are increasingly important in modern Western economies. Landshare (2013) is a UK-based website that describes its purpose as bringing together people who have a passion for home-grown food, connecting those who have land to share with those who need land for cultivating food. Typically, consumers find one another online through localised search results on the homepage. The 'grower' meets the 'provider' through responses to adverts and subsequent dialogue. The system provides an informal mechanism to arrange meetings offline. Often, the resulting exchange of the grower's labour and provider's garden leads to a mutually beneficial outcome, that is, shared producealthough this is not necessarily an obligation on the behalf of the recipient.

The research followed a form of participant-observational netnography as advocated by Kozinets, 2006. Initially, each system was closely examined for over a year; this included analyzing the structural form of each system and how consumers created, captured, broadcast and disseminated data using the internet. The purpose of this preliminary step was to make cultural entrée, to learn about the community and help refine the core research questions. It also provided an opportunity to examine the differences in how the supporting assemblages of web technology were implemented in each case. Specifically, the sites were examined to identify whether they were available on the internet browsers of mobile phones, tablet computers and desktop computers; whether messaging happened through sitespecific instant messaging clients or through external email dialogue; and whether the websites used extra functionality such as blogs and message board forums to support each respective community. According to Langer and Beckman (2005), wherever access to websites is not restricted online, this can be defined as a public communication and for Freecycle, Landshare, and Couchsurfing, this is precisely the case. With this in mind and considering the ethical guidance also suggested by Kozinets (2006), the identity of the researchers was revealed to each community from the start in the interest of promoting openness and cooperation. This was followed by direct observation of the community members. Through note taking and copying examples of computer-mediated communication, this provided an initial corpus for data analysis. Kozinets (2002) suggests that if the researcher seeks to generalise the study to groups beyond the population studied, then other data collection methods should be used to help triangulate the research, that is, depth interviews. Fifteen users of Freecycle, Couchsurfing and Landshare (five each) were selected through purposive 
sampling for depth interviews. Eight women and seven men, with ages varying from 22 to 64 years, participated in the formal interviews. All of the participants were current users of at least one of the respective systems, with two of the participants having also participated as site moderators in the past for Freecycle and Couchsurfing. The research questions used in interviews were loosely informed by Sherry's three-stage model: prestation (decision making), gestation (exchange), and reformulation (consumption and post-consumption). However, because of the dyadic nature of the model of Sherry (1983), the questions were extended to accommodate responses that relate to potentially polyadic interactions. It has also been suggested that Sherry's model has strong theoretical undertones of exchange, even suggesting at the potential of balanced reciprocity. This view has been questioned in subsequent studies (refer to Cheal, 1988; Strathern, 1992; Belk and Coon, 1993) because it relies on the abstraction of all resources as being commensurately divisible and therefore capable of being balanced. Previous studies of Freecycle (Nelson et al., 2007; Nelson and Rademacher, 2009) have also contended that the notion of balanced reciprocity (as described by Sahlins, 1972) is absent in these systems.

The formal interviews began with grand tour style questions (Spradley, 1979) where informants were asked to recall an occasion during which they used a pro-social exchange system successfully. Using online records of previous transactions as prompt, informants were then asked to recall specific interactions and the types of resources that were exchanged. The depth interviews yielded rich information on 49 types of

T1 resources that were exchanged (refer to Table 1). Informants were also asked to recall instances where they had been unable to use the system successfully and elaborate on the factors that they believed contributed to failure. Throughout the interviews, research participants were asked specifically about the long-term relationships formed between donor and recipient. Where there was evidence that participants had only ever interacted once with a donor/recipient, they were asked to reflect on any sense of owing or indebtedness that they may have felt. This was important in the context of how it motivated their subsequent behaviour towards their exchange partners and the wider community. Participants were specifically asked to refer to how the technology they used influenced each of the dimensions discussed earlier: agency, structure, property, and ritual. Rather than asking the questions with explicit reference to each of these dimensions, the participants were asked concise questions such as why they used the system, who they used the system for, how they used the system online and offline, and whether they acted in a particular way when using the system that was specifically unique or based on a particular etiquette. By examining the way consumers interact with each respective digital service, the technology is used as a lens to examine how people negotiate ambiguity. Unlike offline gift giving and sharing where motivations may remain tacit and implicit in action, digitally mediated systems require consumers to explicitly articulate and communicate their desires to negotiate the circumstance of gestation. Participants were all introduced to the research online but interviewed offline in the environment in which they would normally meet other donors/recipients, including homes, gardens, offices, and coffee shops (depending on the resource involved in the respective system). Digital communication trails such as emails and private messaging systems were used for reference

Table 1. Digitally mediated gifts data set

\begin{tabular}{|c|c|c|c|}
\hline $\begin{array}{l}\text { Gifting } \\
\text { system }\end{array}$ & $\begin{array}{l}\text { No. of research participants } \\
\qquad(n=15)\end{array}$ & $\begin{array}{l}\text { Types of resources given by informants } \\
\qquad(n=27)\end{array}$ & $\begin{array}{l}\text { Types of resources received by informants } \\
\qquad(n=21)\end{array}$ \\
\hline Freecycle & 5 & $\begin{array}{l}\text { Washing machine } \\
\text { Steamer } \\
\text { Arch files } \\
\text { Three sofas } \\
\text { Scrap metal } \\
\text { Dining table } \\
\text { Ceramic tiles } \\
\text { Men's bicycle } \\
\text { Piano } \\
\text { Laundry basket } \\
\text { Television and stand } \\
\text { Spice rack } \\
\text { Selection of videos } \\
\text { Baby monitors } \\
\text { Toaster }\end{array}$ & $\begin{array}{l}\text { Left-handed guitar } \\
\text { Leather sofas } \\
\text { Television } \\
\text { Children's scooter } \\
\text { Set of bedside drawers } \\
\text { Filing cabinet } \\
\text { Laundry basket } \\
\text { CDs for children } \\
\text { Travel pram } \\
\text { Mobile phone charger }\end{array}$ \\
\hline Landshare & 5 & $\begin{array}{l}\text { Gardening space } \\
\text { Shed space } \\
\text { Access to tools } \\
\text { Access to running water } \\
\text { Fruit and vegetables }\end{array}$ & $\begin{array}{l}\text { Gardening space } \\
\text { Horse manure } \\
\text { Glass panels } \\
\text { Mulch } \\
\text { Fruit and vegetables }\end{array}$ \\
\hline Couchsurfing & 5 & $\begin{array}{l}\text { Accommodation (bedrooms or living rooms) } \\
\text { Access to kitchen/bathroom facilities } \\
\text { Home-cooked meal } \\
\text { Cup of coffee } \\
\text { Tour guides } \\
\text { Bottle of wine and bottle opener }\end{array}$ & $\begin{array}{l}\text { Accommodation (bedrooms or living rooms) } \\
\text { Access to kitchen/bathroom facilities } \\
\text { Home-cooked meal } \\
\text { Cup of coffee } \\
\text { Tour guides } \\
\text { A meal cooked by a guest }\end{array}$ \\
\hline
\end{tabular}


in order to help elicit specific reference to case histories. Interviews were audio recorded and transcribed before being coded independently. The interviews, computer-mediated communication trails, and field notes were transcribed and analysed using the software package NVivo, which facilitated a thematic coding process. The thematic analysis drew from a realist epistemology premised on the possibility of ontological stratification (refer to Archer, 1995) and was further sensitised by the theoretical dimensions identified in the literature review. Nvivo was thus used as a means to develop a structure of associations and links within the corpus (as advocated by Bazeley and Richards, 2000 and Maclaran and Catterall, 2000). The analysis was iterative in nature and followed a qualitative and hermeneutic process. Once the first phase of coding was finished, it was then used as a basis for discussion between the research team on the emergent global themes. The consensus from these discussions was then used as a basis for reviewing and refining the existing codes.

\section{ANALYSIS}

This research addresses the clarifying role of technology in digitally mediated pro-social exchange systems and raises its importance as a subject for further study. Interestingly, many of the participants defined their participation in these systems not as one of gift giving or sharing as defined and marketed by each respective organisation but rather as one of redistribution or exchange, thus confirming the hybridised nature of these economic transfers as discussed by Dobscha and Arsel (2011). The position adopted throughout the research is etic insofar as it is an attempt to examine the core concepts of agency, structure, property and ritual across cultures rather than through the informants' own construal of their participation within each respective system. Four key themes were identified in the research that related to the clarifying role that technology plays in these economic transfers, including self-curation, partner selection, tenure niche negotiation, and ritual normalisation.

\section{SELF-CURATION}

Participants in the systems gave away and shared a wide variety of resources ranging from horse manure to the door key of a mansion, and the amount of supporting personal information was no less diverse. In each respective system, there are different requirements for revealing personal information to the wider community, and different subsequent strategies that consumers employ for impression management. These vary from revealing only a simple unique personal identifier such as a username up to a comprehensive self-examination of personality made publicly available. Following work by Goffman (1959), the presentation of self has been studied extensively over the past few decades and more recently as it relates to explicitly 'social' networking websites (e.g. Hogan, 2010). However, very little research has examined presentation of self online in relation to gift giving. In these systems, consumers curate the information online that relates to them in order to exhibit an alignment with the type of relationship that is expected between donor and recipient. Freecycle transactions result in complete transferral of ownership, and the level of personal information shared is very limited (generally email address and hometown). A variety of masks and algorithms are deployed to selectively present personal information at opportune moments. User anonymity does not necessarily preclude a change of ownership. Indeed, it may even help to remove any sense of reciprocal obligation on the part of the recipient. As anonymity is often seen as common to gift giving in this context, this behaviour provides both an indication and counter indication of Belk's (2010) tripartite structure and therefore demonstrates ambiguity. Susan, a 32-year-old mother of two and frequent Freecycle user, commented:

I don't care who takes it as long as somebody takes it. I post the ad, reply to the people that have responded with my address, and then I leave whatever it is I' $m$ getting rid of outside for them... I know some Freecyclers want to know who's taking what and whatever they're going to be doing with it, but I'm not bothered about chatting.

This can be contrasted with Couchsurfing where each user creates and maintains a personal profile that is made publicly available. This profile includes a history of previous transactions that demonstrates whether that user has a proven history of trustworthiness. Paul, a 24-year-old sports journalist commented:

Couchsurfing profiles and histories are important. I think it's important to outline your core values in life so you can find people with similar values. I wouldn't put some information online, like relationship details or contact details immediately, but the community has to get a feel for who you are and what Couchsurfing is to you before you meet people. There's a real stigma attached to negative references, so it isn't worth the hassle of touting yourself to people that aren't of a similar ilk.

This emphasis on the creation of transparent consumption histories ensures that negative transactions carry significant negative value for an unreliable host, that is, they will, in theory at least, struggle to yield as many further successful partners within the network. The effect of this is the creation of a state in which the profiles of users are exposed to a feeling of constant observation, which therefore leads to a motivation for vigilance when exchanging with others (Bertucci, 2009). In effect, this can be seen as a positive reinterpretation of the surveillance Panopticon metaphor as described by Foucault (1995) — reputation is used as a coordination mechanism - the façade becomes the function.

\section{PARTNER SELECTION}

In each system examined, the resource in question is always offered in the first instance digitally to the community, encouraging communal responses to an offer online, before individuals are selected to meet offline. All of the research participants using Freecycle or Couchsurfing suggested that it was rare to ever meet partners more than once or indeed 
thought it necessary; however, this was not the case with Landshare. As Landshare encourages long-term sharing, there is more of a requirement to maintain a relationship between donor and recipient. Here, the donor retains the right of alienability but the recipient has excludability, that is, the recipient is granted the right to manage the resource, change it, use it for production and stop others using it-except for the legal owner. Where donors and recipients from Freecycle and Couchsurfing were found to have met more than once, each participant was keen to stress their opposition towards the concept of reciprocal balance. This suggests that to conceive the behaviour simply as an aggregate result of dyadic gift transactions, as other studies have shown (e.g. Sherry, 1983), would be flawed. The systems have developed by helping to reinforce social solidarity in much the same way as intracommunity gifting (as recognised by Weinberger and Wallendorf, 2011) despite the technology here mediating dyadic gestation. No participants expressed any sense of post-transaction obligation or owing to partners, but allegiance was frequently expressed in relation to the brand or cause of the pro-social exchange systems. One Couchsurfing participant had hosted over 150 individual couchsurfers in his home without ever being a surfer himself. When asked why he took part in Couchsurfing, Phil, 54 said:

Well if I' $m$ not going out to see the world at least the world is coming here, and it means I get more use out of this huge house. It's silly having this house for one person. I don't do it to get anything in return but it often leads to interesting experiences with people that I couldn't possibly meet otherwise. Couchsurfing allows me to understand whether or not a person is likely to be trustworthy, if they are going to be interesting, and if they will be right for me.

Price et al. (2000) and have suggested that receiver congruity is a key aspect when people voluntarily dispose of items that have particularly personal meanings attached to them-it is first necessary to identify appropriate recipients for such objects. Cheetham (2009, p.316) notes that previous studies that have analysed receiver congruity have tended to examine familial transfers where consumers select recipients "who will look after the cherished possession but ensuring that they will also appreciate its meanings". For couchsurfers, congruity in selection emerges from participant histories, public profiles and e-mail dialogue. For Freecycle users, many of the items being given away are of little value to the owners, but the selection process can still be rigorous and often comes down to a moral assessment of the recipient. One Freecycle user, Julie (38), uses the system extensively for giving and receiving children's clothing, toys and furniture. When asked about the process, she follows for selecting a recipient she replied:

I expect people to be flexible and polite. I don't like to be a grammar snob but I expect the request to be well written. If the person begs they've got no chance, but I do like to know the story of why the person wants the item. It's nice to know that your item is going be doing something worthwhile, something meaningful, you know? That's the whole point of Freecycling.
Freecycle is marketed in opposition to balanced reciprocity; yet, this counter indication of gift giving is called into question when people use the service with such thoroughly personal disinvestment strategies for their belongings. Despite this perennial hybridity borne of different motivations within the system, the issue of ambiguity can be resolved by allowing the participants to message one another first electronically and select an appropriate partner.

\section{NEGOTIATION OF PROPERTY RIGHTS}

Systems that encourage giving and sharing can be used in relation to different types of property and consumption respectively. A significant distinction was found in relation to whether or not the resource is consumed discretely, that is, as a divisible, individuated experience. Indiscrete consumption occurs when a resource consumed by an individual has a non-subtractive influence on the consumption behaviour of others, that is, two or more people can simultaneously consume the resource without inhibiting one another, for example accommodation. For indiscrete forms of consumption, these systems use graduated hierarchies of property rights, granting the right of exclusion while the donor retains the right of alienability. By explicitly defining the available rights of resources during gestation (i.e. asking the owners of shared resources to articulate the precise property rights they are comfortable with others accessing), this helps to mediate the liminoid moments that punctuate consumption and reformulation. Where participants deviate from the suggested guidelines given in each system, there are potential conflicts of interest. Landshare goes further than Freecycle and Couchsurfing by providing a template for a contractual basis to the shared tenure of growing space. However, some participants were guarded when asked about this formalising process, preferring instead to just identify partners they believed would be trustworthy rather than sour the relationship with strict rules. Consider Suze, 64 who uses the service extensively to find partners but has not used the system to formalise relations:

I've had 6 Landsharers over the past few years and for whatever reason, I've not found somebody that can actually share the land in the truest sense of the word. I don't know whether it's just me or whether, I've been unlucky. Everyone I've had on the land always seemed like nice reasonable people when we first meet, but after a while I find it hard to ask them to change their ways because it perhaps wasn't clear enough at the start. In hindsight I should have used a contract; otherwise access comes to mean ownership, and then conflict, which isn't the way it should be.

Insofar as Freecycle, Couchsurfing and Landshare are concerned, there is a state in which the first potential property right (i.e. digital access or knowledge of the resource) can be attained by the collective without the donor ceding ownership of the resource in question. This is the gift from the one to the many and is the means through which the systems are sustained through indirect reciprocity, i.e. without the need for deep personal connections formed between dyads. 


\section{RITUAL NORMALISATION}

Where pro-social exchange systems record interactions between people, they serve as a form of collective memory. This helps to normalise and reinforce behaviour among those that repeatedly use the system. Perhaps the strongest example of this can be seen in Couchsurfing where all previous transactions are recorded on a public message board for each person involved; wherever consumers transgress the moral expectations of the community, the digital record is used to ostracise and, where possible, reconcile. Couchsurfer participants almost universally rejected the idea that their partners 'owed' anything to them or vice-versa, but they all expressed an expectation of etiquette. Punctuality, cleanliness, gratitude, and willingness to spend time with the host and exchange experiences were all suggested as part of the normal process of Couchsurfing. Greta, a 22 yearold student, is a seasoned Couchsurfer who has stayed in 8 different countries and hosted over 20 guests, she comments:

I expect them to be interested in me as a person and not only interested in spending the night in my house for free. It's essential that the people that ask to stay with me are willing to bring something to the party, so to speak. There's a specific way to behave when you surf. It's doesn't need to be a gift that a surfer brings, particularly as travellers often don't have much money, but I expect them to maybe make dinner. It is customary in my experience for the surfer to make dinner if they are staying for more than one night. It's probably my favourite part as it is a chance to experience other cultures in your own home. I've given negative reviews to people that aren't willing to exchange their experiences with me; I'm not running a hotel.

This suggests that despite the rejection of the system being premised on immediate reciprocity (a counter indication of gift giving), it is not entirely sharing either, as the example demonstrates that personal information may be expected but is not always provided (a counter indication of sharing). An example of a strict symbolic disinvestment ritual was found in Freeycle too where participants expressed a desire to ensure that the system was used properly. Consider, Nicola (36) who commented:

The point of the Freecycle community, if I can call it that, is that these things are meant to be gifts, they aren't meant to be sold. I know the moderators try to crack down on people trying to resell items on Ebay or carboot sales. I don't think it's fair that they should be allowed to use the service.

Some participants expressed strong ideological motivation and eagerness to participate in pro-social exchange systems as a means of subverting the dominance of consumer capitalist hegemony. This tension between the logic of the market and the preservation of a shared sense of community has been recognised elsewhere in previous consumer research (e.g. Holt, 2002; Kozinets, 2002), but little attention has been given to the role technology that can play in sustaining the perceived opposition of market and morality. Sharing taken in this sense is seen as a form of anti-consumption (refer to Ozanne and Ballantine, 2010). In spite of the inevitable ambiguity that arises during giving and sharing, technology is used in pro-social exchange systems to help perpetuate structured consumption patterns. By recording interactions and guidelines, the human-computer interface is used to ingratiate consumers into normalised rituals. Indeed, many of the respondents admitted to adhering to a particular etiquette when offline which they had previously inferred from discussions conducted online.

\section{CONCLUSION}

The online systems that have facilitated new hybridised forms of pro-social exchange are complex and challenging to theorise. However, the four themes identified nonetheless reveal important insights into how technology mediates the ambiguities that arise from hybridization in order to create and perpetuate structured, ritualised behaviour. As mobile computing becomes increasingly pervasive, commercial opportunities for new forms of collaborative consumption are likely to emerge. By examining the human-computer interaction in computer-mediated systems, it is possible to capture and analyse the explicit articulation of circumstance under which giving and sharing systems can emerge. For consumer researchers, these systems can help to provide an insight into the ways resources are appropriated by consumers at individual and collective levels. For practitioners, the four emergent themes of self-curation, partner selection, property right negotiation, and ritual normalisation present opportunities to create innovative new forms of collaborative consumption in sectors traditionally reliant on monetary exchange. These four dimensions could be managed and manipulated in light of the findings presented here in order to optimise the efficacy of other pro-social exchange systems. An example of a pro-social behaviour worthy of further analysis is 'ridesharing', that is, the sharing of car journeys so that more than one person travels in a car. While the social mechanisms behind non-monetised exchange in ride sharing are acknowledged to be critical (Wash et al., 2005), they have not been well addressed by many rideshare schemes, and hence, uptake of technology remains limited at best (Buliung et al., 2010). Consumer researchers (Jonsson, 2007; Bardhi and Eckhardt, 2010, 2012) have identified the increasing demand for access-based consumption in preference to ownership, especially in relation to transportation, but they have also recognised that sustainability marketing campaigns regularly fail. The themes proposed in this paper could be used as a framework to highlight the different characteristics of technology mediated car sharing. For example, the mechanics of partner selection has already been demonstrated to require close consideration in the functional design of ride sharing technology, not just for the logistics of the lift but also for the development of trust and confidence (Brereton and Ghelewat, 2010). Self-curation and explicit negotiation of property rights through the use of user profile web forms could help to increase the likelihood of congruent expectations between system partners. Further analysis of ridesharing in terms of the whole framework will highlight how aspects of the technology can be utilised most effectively. In return, this effort to apply the framework would act as a validation of its scope and appropriateness. 
The findings also provide insights that are useful for policy makers. As environmental and economic pressures continue to mount on organisations and governments alike, newer forms of collaborative consumption are likely to be given increasing recognition in policy. A UK governmental white paper has already acknowledged that these systems provide a vitally important contribution to the economy that is not understood by traditional metrics. "Collaborative consumption will improve economic efficiency in a way that is not necessarily captured by gross domestic product figures" (Department for Business, Innovation and Skills, 2011, p.27). Unlike the popular 'libertarian paternalism' approach of nudging the individual's decision-making towards sustainable alternatives, a focus on group-level collaborative consumption solutions may help to decouple the relentless political pursuit of economic growth from the environmental impact that inevitably accompanies it.

The research design relied on evidence collected from a single locale in the UK, however as these systems are international in nature, it would be interesting to examine cross-cultural significance of pro-social exchange systems. This research has examined the role that technology plays in computer-mediated systems, but an alternative avenue for future research would be an extension of Ruth et al. (1999) study examining the reformulation of intracommunity relationships after gift giving or sharing has occurred. Previous research has examined this phenomenon at an interpersonal level, but in the case of the systems presented here, the singular nature of many of the transactions suggests that of much more importance is the sustained social change brought about by the chosen economic transfers rather than interpersonal relationship maintenance. Depending on the nature of the resource and property rights transferred during exchange, this may create different relational experiences, strengthening or affirming intracommunity bonds in the case of shared property rights or even potentially weakening or severing relationships where alienability is a prerequisite condition of consumption by a single individual.

\section{ACKNOWLEDGEMENTS}

The work was supported by the Horizon Doctoral Training Centre at the University of Nottingham (RCUK Grant No. EP/G037574/1) and part funded by the RCUK Horizon Digital Economy Research grant, EP/G065802/1

\section{BIOGRAPHICAL NOTES}

John Harvey is a PhD candidate in the Horizon Digital Economy research hub at the University of Nottingham. His broad research interests include non-monetary exchange, altruism, gift giving, and interdisciplinary issues in economic anthropology.

Andrew Smith is currently the Professor of Consumer Behaviour at Nottingham University Business School. He has had work published on various aspects of consumer decision making and behaviour including ethical aspects, behavioural data analysis and data management.

\section{REFERENCES}

Abrahams RD. 1969. Foreword in turner. V. - The Ritual Process: Structure and Anti-Structure. Aldine De Gruyter.

Albinnson PA, Perera YB. 2012. Alternative marketplaces in the 21st century: building community through sharing events. Journal of Consumer Behaviour 11: 303-315.

Appadurai A. 1986. Introduction: commodities and the politics of value. In Appadurai A (ed). The Social Life of Things. Cambridge University Press: New York.

Archer M. 1995 Realist Social Theory: The Morphogenetic Approach. Cambridge University Press: Cambridge.

Bardhi F, Eckhardt G. 2010. Market-mediated collaborative consumption in the context of car sharing. Advances in Consumer Research 37: 4-5.

Bardhi F, Eckhardt GM. 2012. Access-based consumption: The case of car sharing. Journal of Consumer Research 39(4 December 2012): 881-898

Barthes R. 1972. Mythologies. Farrar, Straus and Giroux.

Bazeley P, Richards L. 2000. The NVivo Qualitative Project Book. Sage: London.

Belk RW. 2007. Why not share rather than own? Annals of the Q3 American Academy of Political and Social Science 611(May): 126-40.

Belk RW. 2010 Sharing. Journal of Consumer Research 365: 715-734

Belk RW, Coon GS. 1993 Gift giving as agapic love: an alternative to the exchange paradigm based on dating experiences. Journal of Consumer Research 20(3 December 1993): 393-417

Benkler Y. (2004). Sharing nicely: On shareable goods and the emergence of sharing as a modality of economic production. Yale Law Journal 114: 273-358

Bertucci JO. 2009. Lien Social et economic d'hebergement gratuity sur Couchsurfing, Revue du MAUSS. [Online] Available at: http://www.journaldumauss.net/spip.php?article578 Date Accessed: $02 / 02 / 2013$

Botsman R, Rogers R. 2011. What's Mine Is Yours: The Rise Of Collaborative Consumption. Harper Business.

Bradford TW. 2009. Intergenerationally gifted asset dispositions. Journal of Consumer Research, 36 (June): 93-111.

Brereton M, Ghelewat S. 2010. Designing for participation in local social ridesharing networks - grass roots prototyping of IT systems. In Proceedings of PDC '10, Sydney, Australia. 199-202.

Bruce JW. 1995. Legal Bases for the management of land-based natural resources as common property. Rome, Italy: Forests, Trees and People Programme, Food and Agriculture Organization of the United Nations

Buliung RN, Soltys K, Bui R, Habel C, Lanyon R. 2010. Catching a ride on the information super-highway: toward an understanding of internet-based carpool formation and use. Transportation 37 (6): 849-873.

Carrier JG. 1991. Gifts, commodities and social relations: A Maussian view of exchange. Sociological Forum 6: 119-36.

Carrier JG. 1995 Gifts and Commodities: Exchange and Western Capitalism Since 1700. Routledge: London.

Cheal D. 1988 The Gift Economy. Routledge \& Kegan Paul: New York.

Cheetham F. 2009. Out of control? An ethnographic analysis of the disposal of collectable objects through auction. Journal of Consumer Behaviour. 8(6): 316-326.

Clarke JR. 2006. Different to 'dust collectors' ? The giving and receivingof experience gifts. Journal of Consumer Behaviour 5: 533-549.

Commons JR. 1968. Legal Foundations of Capitalism. University of Wisconsin Press: Madison

Couchsurfing. 2013. Vision Statement. [Online] Available at: www. couchsurfing.org , Date Accessed: 15/02/2013

Department for Business, Innovation and Skills. 2011. Better Choices: Better Deals, Consumers Powering Growth, Cabinet Office Behavioural Insights team [Online] Available at: http:// 
www.bis.gov.uk/feeds/ /media/673F5899B57148D29E077E8 B7ECF1D7F.ashx Date Accessed: 15/02/2013

Dobscha S, Arsel Z. 2011. Hybrid Prosocial Exchange Systems: The case of Freecycle. Presented at the ACR's Association of Consumer Research, St. Louis, MO.

Felson M, Spaeth J. 1978. Community structure and collaborative consumption. American Behavioral Scientist 21(4): 614-624.

Foucault M. 1995. Discipline and Punish. The birth of the prison. Vintage: Second Vintage Books Edition.

Q5 Freecyle. 2013. Mission Statement [Online] Available at: www.uk. freecycle.org, Date Accessed: 15/02/2013

Giesler M. 2003. An anthropology of file sharing. Advances in Consumer Research 30: 273-279.

Giesler M. 2006. Consumer gift systems. Journal of Consumer

Q6 Research 33(2).

Godelier M. 1999. The enigma of the gift. Polity Press: Cambridge.

Goffman E. 1959. The presentation of self in everyday life. Anchor Books: New York, NY.

Gregory CA. 1980. Gifts to men and gifts to God: gift exchange and capital accumulation in contemporary Papua. Man (n.s.) 15: 626-52.

Q7 Hann C. 2005 'Property'. In Carrier JG (ed).Handbook of Economic

Q8 Anthropology.

Hess C, Ostrom E. 2003 Ideas, Artifacts, and Facilities: Information as a common-pool resource. Law and Contemporary Problems $66 \mathrm{~S}: 111-146$

Hogan B. 2010. The Presentation of Self in the Age of Social Media: Distinguishing Performances and Exhibitions Online. Bulletin of Science Technology Society, December

Holt DB. 2002 Why do brands cause trouble? A dialectical theory of consumer culture and branding. Journal of Consumer Research 29(1): 70-90

Jonsson P. 2007. A tale of a car sharing organization (CSO) monster. In Brembeck H, Ekstrom KM, Morck M (eds). Little Monsters: (de) coupling assemblages of consumption. Transaction Publishers: New Brunswick; 149-164.

Joy A. 2001. Gift giving in hong kong and the continuum of social ties. Journal of Consumer Research 28 (September): 239-56.

Kozinets RV. 2002a. Can consumers escape the market? Emancipatory illuminations from burning man. Journal of Consumer Research 29: 20-38.

Q9 Kozinets RV. 2002b. The field behind the screen: Using netnography for marketing research in online communities. Journal of Marketing Research 39 (February): 61-72.

Kozinets RV. 2006. Netnography 2.0. In Belk RW (eds). Handbook Q10 of Qualitative Research Methods in Marketing.

Landshare. 2013. - [online] available at: www.landshare.net, Date Q11 Accessed: $15 / 02 / 2013$

Langer R, Beckman SC. 2005. Sensitive research topics: netnography revisited. Qualitative Market Research: An International Journal8(2): 189-203.

Maclaran P, Catterall M. 2000. Analysing qualitative data: computer software and the market research practitioner. Qualitative Market Research: An International Journal 5(1): 28-39.

Malinowski B. 1922/1992. Argonauts of the Western Pacific. Routledge \& Kegan Paul: London.

Mauss M. 1925/1967. The Gift: Forms and Functions of Exchange in Archaic Societies. Cunnison I (ed). Norton: New York.

Nelson MR, Rademacher MA.2009. From trash to treasure: Freecycle.org as a case of generalized reciprocity. Advances in Consumer Research 36: 905-906.
Nelson MR, Rademacher MA, Paek HJ. 2007. Downshifting consumer - upshifting citizen? An examination of a local freecycle community. The Annals of the American Academy of Political and Social Science 611(1): 141-156.

Ostrom E. 2003. How types of goods and property rights jointly affect collective action. Journal of Theoretical Politics 15(3): $239-270$

Ostrom E, Hess C. 2007. A framework for analyzing the knowledge commons. From Understanding Knowledge as a Commons: From Theory to Practice. Hess C, Ostrom E (eds).

Ostrom E, Schlager E. 1996. The formation of property rights. In Hanna S, Fole C, Maler K-G (eds). Rights to Nature. Island Press: Washington, D.C.127-56.

Ozanne LK, Ballantine PW. 2010 Sharing as a form of anticonsumption? An examination of toy library users. Journal of Consumer Behaviour 9: 485-498

Parry J, M Bloch. 1989. Introduction: money and the morality of exchange. In Parry J Bloch M (eds). Money and the morality of exchange. Cambridge University Press: Cambridge.

Parsons E, Maclaran P. 2009. 'Unpacking disposal': introduction to the special issue. Journal of Consumer Behaviour 8: 301-304

Penner LA, Dovidio JF, Piliavin JA, Schroeder DA. 2005. Prosocial behaviour: multilevel perspectives. Annual Review of Psychology 56: 365-392

Price LL, Arnould EJ, Curasi CF. 2000. Older consumers' disposition of special possessions. Journal of Consumer Research 27: 179-201.

Ruth JA, Otnes CC, Brunel FF. 1999. Gift receipt and the reformulation of interpersonal relationships. Journal of Consumer Research 25(4): 385-402.

Sahlins M. 1972. Stone Age Economics. Aldine-Atherton: Chicago.

Sherry JF. 1983. Gift Giving in Anthropological Perspective. The Journal of Consumer Research 10(2).

Spradley J. 1979. The ethnographic interview. Holt, Rinehart, and Winston: New York.

Strathern A. 1979. Gender, ideology and money in Mount Hagen. Man (n.s.) 14: 530-48.

Strathern M. 1992. Qualified Value: the perspective of gift exchange, in Barter, Exchange and Value: an anthropological approach. Cambridge University Press

Turner V. 1969. The Ritual Process: Structure and Anti-Structure. Aldine De Gruyter.

Van Gennep A. 1960. The rites of passage. (Translated by M. B. Vizedom \& G. L. Caffee) University of Chicago Press: Chicago.

Wash R, Hemphill L, Resnick P. 2005. Design decisions in the RideNow project Proceedings of the 2005 international ACM SIGGROUP conference on Supporting group work, November 06-09, 2005, Sanibel Island, Florida, USA.

Weinberger MF, Wallendorf M. 2011. Intracommunity gifting at the intersection of contemporary moral and market economies. Journal of Consumer Research.

Widlock T. 2004. Sharing by default: Outline of an anthropology of virtue. Anthropological Theory 4 (1): 53-70.

Wooten DB. 2000. Qualitative steps toward an expanded model of anxiety in gift-giving. Journal of Consumer Research 27 (June): 84-95.

Wooten DB, Wood SL. 2004. In the Spotlight: The Drama of Gift Reception. In Otnes CC, Lowrey TM (eds). Contemporary Consumption Rituals: A Research Anthology. Mahwah, NJ: Erlbaum; 213-36.

Yan Y.2005. 'The gift and gift economy.' In Carrier JG (ed). Handbook of Economic Anthropology. 